\title{
PENGARUH METODE STAD TERHADAP HASIL BELAJAR MATEMATIKA MAHASISWA
}

\author{
Mahsup, Yunita Septriana Anwar \\ Pendidikan Matematika, Universitas Muhammadiyah Mataram
}

supyeka@gmail.com

\section{INFO ARTIKEL}

\section{Riwayat Artikel:}

Diterima:10 -10-2017

Disetujui:12-12-2017

\section{Kata Kunci:}

Metode STAD

Pemahaman

\section{ABSTRAK}

\begin{abstract}
Abstrak:Tujuan penelitian adalah untuk mengetahui Pengaruh Metode STAD Terhadap Hasil Belajar Matematika Mahasiswa Pada Materi Program Linear Mahamahasiswa Semester IV Program Studi Pendidikan Mataram FKIP UM Mataram. Jenis Penelitian adalah penelitian eksrimen, data yang dikumpulkan berupa hasil tes dan observasi. populasi dan sampel dalam penelitian mahasiswa Semester IV program studi pendidikan matematika. Berdasarkan hasil pengujian hipotesis didapatkan yang telah dilakukan sehingga hipotesis alternatif $(\mathrm{Ha})$ ditolak dan hipotesis nol (Ho) diterima. Sehingga dapat disimpulkan bahwa tidak ada pengaruh metode STAD terhadap prestasi belajar matematika pada materi program linear Mahasiswa Semester IV Program Studi Pendidikan Mataram FKIP UM Mataram
\end{abstract}

\section{A. Latar Belakang}

Pendidikan umumnya dan proses pendidikan khususnya, penggunaan metode yang tepat dalam pengajaran merupakan hal sangat penting, karena keberhasilan pengajaran sangat tergantung kepada cocok tidaknya penggunaan metode pengajaran terhadap suatu topik yang diajarkan sehingga tujuan pengajarannya tercapai dengan baik. Jika pengetahuan tentang metode dapat mengaplikasikannya dengan tepat maka sasaran untuk mencapai tujuan akan makin efektif dan efisien.

Metode atau cara ataupun pendekatan yang diharapkan dapat terlaksana dengan baik, jika materi yang akan diajarkan dirancang terlebih dahulu, misalnya saja dalam menerapkan suatu metode dalam pengajaran matematika sebelumnya menyusun strategi belajar mengajar. Dengan demikian strategi belajar mengajar yang telah disusun dapat ditentukan metode mengajarnya, alat peraga yang digunakan, media pelajaran serta materi pendukung dalam pembelajaran. Suatu pembelajaran dikatakan efektif bila menghasilkan sesuatu sesuai dengan yang diharapkan atau dengan kata lain tujuan tercapai, bila makin tinggi kekuatannya untuk menghasilkan sesuatu makin efektif metode tersebut. Sedangkan metode mengajar dikatakan efisien jika penerapannya dalam menghasilkan yang diharapkan itu relatif menggunakan tenaga, usaha pengeluaran biaya, dan waktu minimum atau semakin kecil tenaga, usaha, biaya dan waktu yang dikeluarkan semakin efisien metode tersebut (Simanjuntak dalam Junaidi, 2012).

Purnomo (1996:6) mengatakan sebagian besar mahamahasiswa mengalami kesulitan memahami konsep Aljabar Linear. Dari nilai semester sebelumnya mahamahasiswa Semester III dapat dilihat nilai ratarata matematika pada materi Program Linear hanya $52 \%$ mahamahasiswa yang belum mencapai ketuntasan. Berdasarkan persentase tingkat ketercapaian hasil belajar mahamahasiswa dengan mengacu pada teori belajar tuntas (mastery learning), Mukminah (2003:14) menyatakan bahwa mahamahasiswa harus menguasai sekurangkurangnya $65 \%$ dari kompetensi dasar yang ditetapkan. Di antara kesulitan mahasiswa adalah kesulitan dalam membuat model matematika, 
menentukan daerah penyelesaian dan melakukan itersasi dengan metode simplek.

Memulai pembelajaran dengan melibatkan mahamahasiswa secara aktif dalam menemukan konsep-konsep, struktur-struktur sampai kepada teorema atau rumus-rumus merupakan ciri dari pembelajaran dengan metode STAD. Pembelajaran dimulai dengan melibatkan mahamahasiswa secara aktif untuk menemukan pengetahuan baru berdasarkan pengetahuan yang telah dimilikinya.

Memulai pembelajaran dengan melibatkan mahamahasiswa secara aktif dalam menemukan konsep-konsep, struktur-struktur sampai kepada teorema atau rumus-rumus merupakan ciri dari pembelajaran dengan metode STAD. Pembelajaran kooperatif tipe STAD merupakan salah satu pembelajaran kooperatif yang paling sederhana terutama bagi dosen yang baru mau mulai beranjak menggunakan "teacher centered" menuju ke "student centered " dan pembelajaran ini merupakan pembelajaran yang motivasional yang diyakini dapat meningkatkan kemampuan pemecahan masalah khususnya pada pokok bahasan tabung dan kerucut karena model pembelajaran ini berorientasi pada mahamahasiswa.

Pembelajaran kooperatif tipe STAD memiliki kelebihan yaitu: (a) mahamahasiswa bertanggungjawab terhadap proses belajarnya, terlibat secara aktif dan memiliki usaha yang lebih besar untuk berprestasi, (b) mahamahasiswa mengembangkan kemampuan tingkat tinggi dan berpikir kritis. Mahamahasiswa yang aktif terlibat dalam pembelajaran ini memiliki konsentrasi yang lebih baik dibanding dengan mahamahasiswa yang hanya mendengarkan ceramah, (c) hubungan yang lebih positif antar mahamahasiswa dengan dilatih untuk bekerjasama dan saling mendengarkan pendapat teman untuk mencapai suatu kesepakatan.

Berdasarkan uraian di atas, dapat disimpulkan bahwa penerapan metode STAD untuk mempelajari materi Program Linear sangat diperlukan. Dengan metode STAD mahamahasiswa tidak sekedar menghafal Program Linear tetapi akan aktif terlibat secara fisik dan mental untuk menemukan rumus tersebut. Metode STAD akan memberi kebebasan kepada mahamahasiswa untuk mengembangkan cara berpikirnya dan dapat membuat mahamahasiswa mengetahui kemampuannya sendiri.

Tujuan penelitian adalah untuk mengetahui Pengaruh Metode STAD Terhadap Hasil Belajar Matematika Mahasiswa Pada Materi Program Linear Mahamahasiswa Semester IV Program Studi Pendidikan Mataram FKIP UM Mataram. Rumusan hipotesis penelitian yaitu :
Ho : Tidak ada pengaruh Metode STAD Terhadap Hasil Belajar Mahamahasiswa Pada Materi Vektor Ruang-2 dan Ruang-Mahamahasiswa Semester III Program Studi Pendidikan Mataram FKIP UM Mataram.

$\mathrm{Ha}$ : Ada pengaruh Metode STAD Terhadap Hasil Belajar Mahamahasiswa Pada Materi Program Linear Mahamahasiswa Semester III Program Studi Pendidikan Mataram FKIP UM Mataram.

\section{B. METODE PENELITIAN}

\section{Jenis Penelitian}

Jenis penelitian yang digunakan dalam penelitian ini adalah Penelitian Eksperimen. Penelitian percobaan (Eksperimental Research) adalah penelitian yang terlihat adanya akibat setelah subjek dikenai perlakuan pada variabel bebasnya (Subana $d k k$, 2001:39). Jadi, penelitian eksperimen adalah penelitian yang bertujuan melihat hubungan sebab akibat.

Penelitian Eksperimen ini digunakan untuk menyelidiki kemungkinan ada tidaknya Pengaruh Metode STAD Terhadap Prestasi Belajar Matematika Mahamahasiswa Pada Materi Program Linear program studi Pendidikan Mataram FKIP UM Mataram.

Dalam penelitian ini terdapat dua kelompok atau kelas yaitu kelas kontrol dan kelas eksperimen. Kelas Eksperimen diberikan perlakuan metode STAD sedangkan pada kelas kontrol tanpa diberikan perlakuan atau tidak menggunakan Metode STAD.

Untuk mengetahui tingkat penguasaan terhadap proses pengajaran dilakukan tes hasil belajar, tes ini diberikan akhir pembelajaran pada pokok bahasan yang telah diberikan, nilai yang diperoleh dari tes tersebut akan dianalisa dengan rumus perbedaan t-tes, dengan tujuan untuk nilai mana yang lebih baik (efektif) diantara nilai kelas kontrol dan kelas eksperimen.

Desain pembelajaran yang digunakan dalam penelitian ini adalah The Static Group Comparison : Randomized control group only design. Rancangan ini terdiri atas dua kelompok, satu kelompok Eksperimen yang diberikan perlakuan dan satu kelompok kontrol yang tidak diberikan perlakuan. Pada keduanya dilakukan pasca-uji dan hasilnya dibandingkan.

Tabel 1

Rancangan Desain Pembelajaran

\begin{tabular}{lccc}
\multicolumn{1}{c}{ Kelompok } & Pretest & Perlakuan & Posttest \\
\hline Eksperimen & - & $\mathrm{X}$ & $\mathrm{T}_{2}$ \\
\hline Kontrol & - & - & $\mathrm{T}_{2}$ \\
\hline \multicolumn{4}{l}{ M. Subana dan Sudrajat $(2001: 10 O)$}
\end{tabular}




\section{Populasi dan Sampel}

\section{a. Populasi}

Menurut Suharsimi (Subana dkk, 2000:24), Populasi adalah keseluruhan subjek penelitian. Sedangkan menurut Nawawi (Subana $d k k$, 2000:24) mengatakan bahwa Populasi adalah keseluruhan objek penelitian yang dapat terdiri dari manusia, benda, hewan, tumbuhan, gejala, nilai tes, atau peristiwa sebagai sumber data yang mewakili karakteristik tertentu dalam suatu penelitian. Adapun populasi dalam penelitian mahasiswa Semester IV program studi pendidikan matematika.

b. Sampel

Meneliti sebagian dari populasi disebut Sampel (Subana $d k k$, 2000:25). Jadi yang menjadi sampel pada penelitian ini adalah sebagian mahamahasiswa yang dijadikan suatu responden. Adapun sampel yang diambil dalam penelitian ini mahamahasiswa Semester IV program studi pendidikan matematika.

\section{Data Penelitian}

Jenis data yang digunakan dalam penelitian ini adalah data kuantitatif. Adapun sumber data yang digunakan oleh peneliti adalah primer dan data sekunder. Data primer adalah data dikumpulkan atau diolah sendiri. Sedangkan data sekunder adalah data yang diperoleh dari suatu lembaga dalam bentuk yang sudah jadi. (Subana $d k k, 2000: 21$ ).

\section{Teknik Pengumpulan Data}

Data yang dikumpulkan dalam penelitian digunakan menguji hipotesis atau untuk menjawab pertanyaan yang dirumuskan. Karena data yang diperoleh akan dijadikan landasan dalam mengambil kesimpulan, data yang dikumpulkan haruslah data yang benar (Subana $d k k$, 2000: 28). Ada beberapa teknik pengumpulan data yaitu :

\section{a. Observasi}

Observasi adalah metode atau cara-cara menganalisis dan mengadakan pencatatan secara sistematis mengenai tingkah laku dengan melihat atau mengamati individu atau kelompok secara langsung (Purwanto, 2012 : 149).

Observasi digunakan untuk mengamati aktivitas mahamahasiswa dan aktivitas dosen selama proses pembelajaran matematika berlangsung. Alat bantu yang digunakan adalah lembar observasi aktivitas belajar mahamahasiswa dan lembar observasi aktivitas dosen. Aktivitas mahamahasiswa selama pembelajaran diamati dalam selang waktu 10 menit dengan menggunakan lembar khusus, begitu pula dengan aktivitas dosen diobservasi dengan lembaran yang telah disediakan.

b. Tes

Tes adalah serangkaian pertanyaan atau latihan yang digunakan untuk mengukur keterampilan, penetahuan, kemampuan, atau bakat yang dimiliki oleh mahasiswa. Penelitian ini yaitu penelitian eksperimen murni, artinya tidak ada refleksi untuk mengulang kembali halhal yang telah diteliti, penelitian ini hanya ingin mengetahui hasil akhir dari proses belajar mengajar dengan menggunakan metode STAD. Adapun langkah-langkah pengumpulan data dalam penelitian ini antara lain :

1) Mahamahasiswa yang dijadikan responden terlebih dahulu diberikan tes awal untuk menentukan kemampuan awal mahamahasiswa sebelum menggunakan metode STAD

2) Kemudian responden dibagi menjadi dua guna untuk menentukan kelas eksprimen dan kelas kontrol.

3) Setelah dilakukan pelajaran dengan menggunakan metode STAD terhadap prestasi belajar matematika mahamahasiswa Semester IIII. Lalu semua responden diberi tes guna untuk mengetahui yang digunakan. Data yang sudah dikumpulkan dianalisis mengunakan regresi sederhana.

\section{Uji instrument tes}

Instrumen yang digunakan adalah lembar tes berupa tes pilihan ganda. Untuk menjamin suatu tes yang disusun tersebut dapat menggambarkan kemampuan mahamahasiswa dengan tepat maka terlebih dahulu dilakukan uji validitas dan reliabilitas

a. Uji Validitas

Sebuah tes dikatakan valid apabila tes itu dapat tepat mengukur apa yang hendak diukur. Istilah "valid "sangat sukar dicari gantinya. Ada istilah baru yang mulai diperkenalkan yaitu sahih, sehingga validitas diganti dengan kesahihan. Walaupun istilah " tepat " belum dapat mencakup semua arti yang tersirat dalam kata " valid ", dan kata " tepat " kadang-kadang digunakan dalam konteks yang lain, akan tetapi tambahan kata " tepat " dalam menerangkan kata " valid " dapat menjelaskan apa yang dimaksud (Suharsimi Arikunto, 2011 : 59).

Untuk menguji validitas dapat menggunakan rumus korelasi product moment yang dikemukakan oleh Suharsimi Arikunto (2011 : 72 ), yaitu :

$$
\mathbf{r}_{\mathbf{x y}}=\frac{\mathbf{N} \sum \mathbf{X Y}-\left(\sum \mathbf{X}\right)\left(\sum \mathbf{Y}\right)}{\sqrt{\left\{\mathbf{N} \sum \mathbf{X}^{2}-\left(\sum \mathbf{X}\right)^{2}\right\}\left\{\mathbf{N} \sum \mathbf{Y}^{2}-\left(\sum \mathbf{Y}\right)^{2}\right\}}}
$$

Nilai $r_{x y}$ dikonsultasikan dengan tabel $\mathrm{r}$ product moment dengan taraf signifikan $5 \%$. Kriteria soal valid, yaitu : Jika nilai $r_{x y}>\mathrm{r}_{\text {tabel, }}$ maka soal tersebut dikatakan valid. Jika nilai $\mathrm{r}_{\mathrm{xy}}<\mathrm{r}_{\text {tabel }}$, maka soal tersebut dikatakan tidak valid. 
b. Uji Reliabilitas

Kata reliabilitas dalam bahasa Indonesia diambil dari kata reliability, dalam bahasa Inggris berasal dari kata reliable yang artinya dapat dipercaya ( Suharsimi Arikunto, 2011:59). Uji reabilitas dengan menggunakan rumus K-R 20 (Suharsimi Arikunto, 2011 : 101), yaitu:

$$
r_{11}=\left(\frac{k}{k-1}\right)\left(\frac{S B^{2}-\sum p q}{S B^{2}}\right)
$$

(Suharsimi Arikkunto, 2011:97) yaitu :

$$
\mathrm{S}^{2}=\frac{\sum \mathrm{X}^{2}-\frac{\left(\sum \mathrm{X}\right)^{2}}{\mathrm{~N}}}{\mathrm{~N}}
$$

Harga $r_{11}$ yang diperoleh kemudian dikonsultasikan keharga r-tabel pada taraf signifikan 5\%. Jika harga $r_{11}$ lebih besar dari harga r-tabel, maka tes tersebut reliabel.

Nilai $r_{11}$ dikonsultasikan dengan tabel $r$ product moment. Kriteria soal reliabel, yaitu : Jika nilai $r_{11}>r_{\text {tabel }}$, maka soal tersebut dikatakan reliabel. Jika nilai $r_{11}<r$ tabel, maka soal tersebut dikatakan tidak reliabel.

\section{Variabel Penelitian}

Variabel adalah objek penelitian, atau apa yang menjadi titik perhatian suatu penelitian (Suharsimi Arikunto, 1993; 91).

Variabel yang digunakan penelitian ini adalah:

$\mathrm{X}=$ Pengaruh yang menggunakan model pembelajaran STAD terhadap prestasi belajar mahamahasiswa pada materi Program Linear Semester IIII program studi Pendidikan FKIP UM Mataram

$\mathrm{Y}=$ Pengaruh yang tidak menggunakan model pembelajaran STADterhadap prestasi belajar matematika mahamahasiswa pada Program Linear Semester IIII program studi Pendidikan FKIP UM Mataram

\section{Analisis Data}

Dalam penelitian ini untuk menganalisis data dari data yang telah terkumpul dapat menggunakan analisa statistik.

Statistik adalah ilmu pengetahuan yang berhubungan dengan cara-cara pengumpulan data, pengolahan data, penarikan kesimpulan, dan membuat keputusan yang cukup beralasan berdasarkan fakta yang ada (Subana dkk, 2000 : 12).

Analisis data yang digunakan untuk menguji hipotesis adalah menggunakan uji t. Sebelum dilakukan uji tersebut sebelumnya dilakukan uji persyaratan yaitu uji normalitas data dan homogenitas varians.
a. Uji Normalitas Data

Untuk mencari kecocokan atau untuk menguji apakah data tersebut terdistribusi normal atau tidak, uji normalitas dapat dihitung dengan rumus:

$$
X^{2}=\sum \frac{\left(f_{o}-f_{h}\right)^{2}}{f_{h}}
$$

Kaidah keputusan:

1) Jika $X^{2}$ hitung $>X^{2}$ tabel, maka distribusi data tidak normal.

2) Jika $X^{2}$ hitung $\leq X^{2}$ tabel, maka distribusi data normal

Jika $X^{2}{ }_{\text {hitung }}<X^{2}$ tabel, maka kedua kelompok sampel tersebut variannya tidak berbeda secara signifikan atau disebut Normal.

b. Uji Homogenitas

Uji homogenitas adalah untuk menguji varians tersebut homogen atau tidak, uji dilakukan dengan rumus sebagai berikut:

$$
F=\frac{\text { Varianterbesar }}{\text { Varianterkecil }}
$$

Dengan kriteria penguji sebagai berikut:

3) Jika $F_{\text {hitung }} \geq F_{\text {tabel, }}$, berarti tidak homogen.

4) Jika $F_{\text {hitung }} \leq F_{\text {tabel }}$, berarti homogen. Varians masing-masing kelas diperoleh dari :

$$
S^{2}=\frac{\sum X^{2}-\frac{\left(\sum X\right)^{2}}{N}}{N}
$$

c. Pengujian Hipotesis

Pengujian hipotesis dengan menggunakan rumus statistik uji t.

Uji $t$ adalah tes statistik yang dapat dipakai untuk menguji perbedaan atau kesamaan dua perlakuan atau dua kelompok yang berbeda dengan prinsip membandingkan rata-rata kedua kelompok perlakuan itu (Subana dkk, 2001:158).

Kriteria hasil uji t-tes sebagai berikut:

1) Jika $t_{\text {hitung }} \geq t_{\text {tabel}}$, maka Ho ditolak dan $\mathrm{Ha}$ diterima

2) Jika $t_{\text {hirung }}<t_{\text {tabel}}$, maka Ho diterima dan $\mathrm{Ha}$ ditolak

Prosedur yang dilakukan dalam uji "t" adalah sebagai berikut :

1) Menetukan nilai rata-rata hitung kelas eksperimen dan kelas kontrol dengan rumus :

$$
X=\frac{\sum X}{N}
$$

2) Varian masing-masing kelas diperoleh dengan rumus:

$$
S^{2}=\frac{\Sigma X^{2}-\frac{(\Sigma X)^{2}}{N}}{N}
$$

3) Menghitung deviasi standar gabungan ( dsg ) dengan rumus : 


$$
\operatorname{dsg}=\sqrt{\frac{\left(n_{1}-1\right) v_{1}+\left(n_{2}\right) v_{2}}{n_{1}+n_{2}-2}}
$$

4) Menentukan $t$-hitung dengan rumus

$$
\mathrm{t}=\frac{\overline{\mathrm{X}}_{1}-\overline{\mathrm{X}}_{2}}{\mathrm{dsg} \sqrt{\frac{1}{\mathrm{n}_{1}}+\frac{1}{\mathrm{n}_{2}}}}
$$

\section{HASIL DAN PEMBAHASAN}

\section{Uji Normalitas}

\section{Tabel 2}

Uji Normalitas Data Pre-Tes

\begin{tabular}{ccccc}
\hline Kelas & $\mathbf{N}$ & $X^{2}$ hitung & $X^{2}$ tabel & Kesimpulan \\
\hline Eksperimen & 15 & $-43,73$ & 11,07 & Normal \\
\hline Kontrol & 15 & $-11,42$ & 11,07 & Normal \\
\hline
\end{tabular}

Tabel 2. menunjukkan bahwa hasil perhitungan uji normalitas data pre-test kelas eksperimen dan kelas kontrol dengan membandingkan harga chi kuadrat hitung dengan chi kuadrat tabel. Dari hasil analisis diperoleh $X_{\text {hitung }}^{2}=-43,73$ dan $X_{\text {tabel }}^{2}=11,07$. Karena $X_{\text {hitung }}^{2}<$ $X_{\text {tabel }}^{2}$ berarti data pada kelas eksperimen yang diperoleh berdistribusi normal. Sedangkan hasil uji normalitas pada kelas kontrol diperoleh $X_{\text {hitung }}^{2}=$ 11,42 dan $X_{\text {tabel }}^{2}=11,07$. Karena $X_{\text {hitung }}^{2}<X_{\text {tabel }}^{2}$ berarti data yang diperoleh berdistribusi normal. Jadi nilai awal pada kelompok kontrol dan eksperimen berdistribusi normal.

Tabel 3

Uji Normalitas Data Postes

\begin{tabular}{ccccc}
\hline Kelas & $\mathbf{N}$ & $X^{2}{ }_{\text {hitung }}$ & $X^{2}{ }_{\text {tabel }}$ & Kesimpulan \\
\hline Eksperimen & 15 & $-23,83$ & 11,07 & Normal \\
\hline Kontrol & 15 & $-23,16$ & 11,07 & Normal \\
\hline
\end{tabular}

Tabel 3 menunjukkan bahwa hasil perhitungan uji normalitas data pos-test kelas eksperimen dan kelas kontrol dengan membandingkan harga chi kuadrat hitung dengan chi kuadrat tabel. Dari hasil analisis diperoleh $X_{\text {hitung }}^{2}=-23,83$ dan $X_{\text {tabel }}^{2}=11,07$. Karena $X_{\text {hitung }}^{2}<$ $X_{\text {tabel }}^{2}$ berarti data pada kelas eksperimen yang diperoleh berdistribusi normal. Sedangkan hasil uji normalitas pada kelas kontrol diperoleh $X_{\text {hitung }}^{2}=$ 23,16 dan $X_{\text {tabel }}^{2}=11,07$. Karena $X_{\text {hitung }}^{2}<X_{\text {tabel }}^{2}$ berarti data yang diperoleh berdistribusi normal. Jadi nilai akhir pada kelompok eksperimen dan kontrol berdistribusi normal

\section{Uji Homogenitas}

Tabel 4

\begin{tabular}{|c|c|c|c|c|}
\hline Kelas & $\mathbf{N}$ & F_hitung & $\begin{array}{c}\text { F_tabe } \\
1\end{array}$ & Ket \\
\hline Eksperimen & 15 & 1,535 & 2,12 & Homogen \\
\hline Kontrol & 15 & & & \\
\hline
\end{tabular}

Uji Homogenitas Data Postes

Tabel 4 menunjukan bahwa hasil perhitungan pada data postes diperoleh $\mathrm{F}_{\text {hitung }}=1,535$ dan Ftabel $=2,12$ pada taraf signifikan $5 \%$ dengan $\mathrm{dk}$ pembilang $(n-1)=21-1=20$ dan dk penyebut $(n-1)$ $=21-1=20$, tampak bahwa Fhitung $<$ Ftabel sehingga menunjukkan varians homogen.

\section{Uji Hipotesis}

Setelah diketahui data hasil postes distribusi normal dan homogen, maka selanjutnya kedua kelas dilakukan uji perbedaan prestasi belajar matematika mahasiswa sesuai dengan hipotesis yang telah ditentukan dengan menggunakan uji-t dengan persamaan sebagai berikut:

$$
t=\frac{\overline{X_{1}}-\overline{X_{2}}}{\operatorname{dsg} \sqrt{\frac{1}{n_{1}}+\frac{1}{n_{2}}}}
$$

Dengan analisis t-test penulis ingin membuktikan ada dan tidaknya pengaruh model pembelajaran STAD terhadap prestasi belajar matematika mahasiswa pada materi pokok program linear

Untuk menguji kreteria "t" maka diajukan hipotesis yaitu "Ha diterima jika $\mathrm{t}$ hitung $>\mathrm{t}$ tabel" dengan $\mathrm{dk}=\mathrm{N} 1+\mathrm{N} 2-2$ pada taraf signifikan $5 \%$ dengan uji satu pihak. Berdasarkan pengujian yang dilakukan, maka didapatkan thitung $=2,593$ sedangkan $t_{\text {tabel }}=2,02$ dapat disimpulkan bahwa $t$ hitung $=2,593>\mathrm{t}$ tabel $=2,02$ ini berarti bahwa hipotesis alternatif (Ha) diterima.

Jadi dapat disimpulkan bahwa "ada pengaruh model pembelajaran STAD terhadap prestasi belajar matematika mahasiswa pada materi pokok program linear

\section{Hasil Observasi}

Berdasarkan hasil observasi pengelolaan dosen pada pembelajaran II kelas eksperimen selama pembelajaran memperoleh skor 27 dengan persentase kemampuan dosen mengelola pembelajaran $61,36 \%$. Untuk selengkapnya perkembangan kemampuan dosen dalam mengelola pembelajaran terdapat pada lampiran 
27. Berdasarkan hasil observasi mahasiswa pada pembelajaran III secara ringkas dapat dilihat pada tabel 5 .

Tabel 5 Hasil Observasi Mahasiswa

\begin{tabular}{lc}
\hline Item & Hasil diperoleh \\
\hline $\begin{array}{l}\text { Jumlah mahasiswa } \\
\text { seluruhnya }\end{array}$ & 15 \\
\hline Banyak aspek yang diamati & 5 \\
\hline Skor total & 20 \\
\hline Skor yang diperoleh & 13 \\
\hline Persentase & $65 \%$ \\
\hline
\end{tabular}

Pada pembelajaran III skor yang diperoleh 13 dengan persentase aktivitas mahasiswa selama pembelajaran sebesar 65\%. Selengkapnya perkembangan aktivitas mahasiswa selama pembelajaran terdapat pada lampiran 28. Selanjutnya hasil observasi dosen pada pembelajaran III secara ringkas dapat dilihat pada tabel 6 .

Tabel 6

Hasil Observasi Dosen Pada Pembelajaran III

\begin{tabular}{lc}
\hline \multicolumn{1}{c}{ Item } & $\begin{array}{l}\text { Hasil yang } \\
\text { diperoleh }\end{array}$ \\
\hline Jumlah skor aktivitas dosen & 29 \\
\hline Jumlah skor seluruhnya & 44 \\
\hline Banyak aspek yang diamati & 11 \\
\hline Persentase & $65,90 \%$ \\
\hline Kategori & Baik \\
\hline
\end{tabular}

Berdasarkan hasil observasi pengelolaan dosen pada pembelajaran III kelas eksperimen selama pembelajaran memperoleh skor 29 dengan persentase kemampuan dosen mengelola pembelajaran 65,90\%.

\section{Hasil Tes}

Hasil perhitungan SPSS dengan taraf sig 5\% di peroleh 0,186 , dengan demikian hipotesis alternatif (Ha) ditolak dan hipotesis nol (Ho) diterima. Sehingga dapat disimpulkan bahwa tidak ada pengaruh metode STAD terhadap prestasi belajar matematika pada materi program linear Mahasiswa Semester IV Program Studi Pendidikan Mataram FKIP UM Mataram.

\section{KESIMPULAN DAN SARAN}

\section{Kesimpulan}

Berdasarkan hasil pengujian hipotesis didapatkan yang telah dilakukan sehingga hipotesis alternatif (Ha) ditolak dan hipotesis nol (Ho) diterima. Sehingga dapat disimpulkan bahwa tidak ada pengaruh metode STAD terhadap prestasi belajar matematika pada materi program linear Mahasiswa Semester IV Program Studi Pendidikan Mataram FKIP UM Mataram.

\section{SARAN}

\section{a. Kepada Mahasiswa}

Bagi mahasiswa diharapkan membiasakan diri untuk menanyakan materi yang dianggap sulit dan belum dimengerti serta tanpa ragu menanggapi pertanyaan-pertanyaan dari dosen maupun temantemannya.

\section{b. Bagi Peneliti}

Bagi peneliti untuk kedepannya diharapkan dapat lebih profesional dalam menerapkan model pembelajaran STAD dan mencoba menerapkannya pada materi pokok yang lain dengan cakupan yang lebih luas.

\section{DAFTAR PUSTAKA}

[1]. Arikunto, Suharsimi. 2011. Dasar-Dasar Evaluasi Pendidikan. Jakarta: Bumi Aksara.

[2]. Djamarah, S. B. 2012. Prestasi Belajar Dan Kompetensi Dosen. Surabaya: Usaha Nasional.

[3]. Fikri, Yusuf. 2013. Model Pembelajaran Snowball Throwing. Didownload dari

http://zoaet.blogspot.com/2013/o2/modelpembelajaran-snowball-throwing.html. Diakses pada tanggal 7 Mei 2013.

[4]. Irzani, 2010. Matematika 1 Untuk Calon Dosen $S D / M I$. Yogyakarta: Kurnia Kalam Semesta.

[5]. Junaidi, Wawan. 2012. Metode Mengajar Matematika dalam Simanjuntak, Lisnawati Dra.,dkk. Metode Mengajar Matematika 1. Didownload dari http://wawanjunaidi.blogspot.com/2012/02/metodemengajar-matematika.html. Diakses pada tanggal 30 April 2013.

[6]. Nuharini, Dewi. 2008. Matematika Konsep dan Aplikasinya Kelas 7 SMP. Bandung: CV Usaha Makmur.

[7]. Purwanto, Ngalim. 2012. Prinsip-Prinsip Dan Teknik Evaluasi Pengajaran. Bandung: PT Remaja Rosdakarya.

[8]. Slameto, Drs. 2010. Belajar dan Fakto-Faktor Yang Mempengaruhi. Jakarta: Rineka Cipta.

[9]. Subana, dkk. 200o. Statistik Pendidikan. Bandung: CV Pustaka Setia.

[10]. Subana, M dan Sudrajat. 2001. Dasar-Dasar Penelitian Ilmiah. Bandung: CV Pustaka Setia.

[11]. Suprijono, Agus. 2009. Cooperative Learning Teori dan Aplikasi PAIKEM. Yogyakarta: Pustaka Pelajar. 
[12]. Syahrir. 2010. Metodologi Pembelajaran Matematika. Yogyakarta: Naufan Pustaka.

[13]. Trianto. 2010. Mendesain Model Pembelajaran Inovatif-Progresif: Konsep, Landasan, dan Implementasinya pada Kurikulum Tingkat Satuan Pendidikan (KTSP). Jakarta: Kencana Prenada Media Group. 